Proc. Estonian Acad. Sci. Eng., 2005, 11, 3, 198-206

\title{
Simulation and analysis of thermal performance of an apartment building
}

\author{
Kadi Kusnetsov and Teet-Andrus Kõiv \\ Department of Environmental Engineering, Tallinn University of Technology, Ehitajate tee 5, \\ 19086 Tallinn, Estonia; takoiv@edu.ttu.ee \\ Received 23 December 2003, in revised form 2 February 2005

\begin{abstract}
The paper describes results of the computer simulation of the thermal performance of an apartment building. Results concerning heat requirements, heating load and indoor climate simulation are given. Applying heating load analysis in apartment buildings without individual temperature control, it is possible to reduce heat consumption for heating.
\end{abstract}

Key words: apartment building, thermal performance, simulation, TRY.

\section{INTRODUCTION}

For heat requirement and indoor climate investigation in buildings, simulation is often used. Simulation of the building performance gives information about heat flows, indoor climate and the behaviour of constructions. The simulated apartment building has a heating system with an ideal control system and an uncontrolled natural ventilation system.

First stage of the simulation was collection of the weather data and Test Reference Years (TRY) compiling. TRY is a common name for weather data for simulating the performance of solar energy and building heat requirements and for indoor climate calculations. A TRY consists of hourly values for a period of one year of a number of weather parameters that are important for abovementioned calculations. Because of the large amount of data, TRY is used only for computerized calculations.

The most important weather parameters must be as near as possible to the actual mean values over a longer period, e.g. a month; natural distribution of higher and lower values should be as close as possible to values for single days. The data in the TRY must have a true correlation between different parameters as temperature, solar radiation, cloud cover, winds, etc. 
It is necessary to use real data measured simultaneously [ $\left.{ }^{1}\right]$. As one of the main purposes of a TRY is to assess the influence of solar radiation, it is necessary to use detailed solar radiation data.

The Estonian TRY is compiled on the basis of the weather data of the Tartu Meteorological Station in the years 1991-2000. From this 10-year period we have chosen the average ambient temperatures for each month, which are close to the average month's temperatures in Estonia. On the basis of these ambient monthly temperatures we have chosen the months that are closer to the ambient temperature, measured at the Tartu Meteorological Station in the years 19912000. By choosing a specific month of a year we have also taken into account the total solar radiation level, which must be close to the average level. All the respective hourly parameters (Table 1) have been obtained from the database of the ambient climate parameters of the chosen month.

Beside TRY, various names have been given to weather data collections: Typical Meteorological Year (TMY, in the US), Standard Weather Data (in Japan), Example Year (in UK). In Table 1, Estonian TRY parameters for one winter day are given as an example.

Table 1. Estonian TRY parameters for one winter day

\begin{tabular}{r|c|c|c|c|c|c}
\hline Hour & $\begin{array}{c}\text { Dry bulb } \\
\text { temperature, } \\
{ }^{\circ} \mathrm{C}\end{array}$ & $\begin{array}{c}\text { Humidity } \\
\text { ratio, } \\
\mathrm{kg} / \mathrm{kg}\end{array}$ & $\begin{array}{c}\text { Wind } \\
\text { speed, } \\
\mathrm{m} / \mathrm{s}\end{array}$ & $\begin{array}{c}\text { Cloud } \\
\text { cover, } \\
\text { octa }\end{array}$ & $\begin{array}{c}\text { Normal } \\
\text { radiation, } \\
\mathrm{kW} / \mathrm{m}^{2}\end{array}$ & $\begin{array}{c}\text { Diffuse } \\
\text { radiation, } \\
\mathrm{kW} / \mathrm{m}^{2}\end{array}$ \\
\hline 1 & -15.7 & 0.001 & 0 & 2 & 0 & 0 \\
2 & -15.3 & 0.001 & 1 & 1 & 0 & 0 \\
3 & -14.8 & 0.0011 & 1 & 0 & 0 & 0 \\
4 & -14.7 & 0.0011 & 1 & 1 & 0 & 0 \\
5 & -14.7 & 0.0011 & 1 & 2 & 0 & 0 \\
6 & -14.6 & 0.0011 & 1 & 2 & 0 & 0 \\
7 & -13.4 & 0.0012 & 1 & 2 & 0 & 0 \\
8 & -12.3 & 0.0014 & 1 & 2 & 0 & 0 \\
9 & -11.1 & 0.0015 & 1 & 2 & 0 & 0 \\
10 & -10.9 & 0.0015 & 1 & 2 & 0.051 & 0.025 \\
11 & -10.7 & 0.0016 & 2.1 & 2 & 0.338 & 0.05 \\
12 & -10.5 & 0.0016 & 2.1 & 2 & 0.482 & 0.072 \\
13 & -11.1 & 0.0015 & 2.1 & 2 & 0.271 & 0.075 \\
14 & -11.7 & 0.0014 & 2.1 & 2 & 0.019 & 0.067 \\
15 & -12.3 & 0.0014 & 2.1 & 2 & 0.055 & 0.033 \\
16 & -12.6 & 0.0013 & 2.1 & 2 & 0 & 0 \\
17 & -13 & 0.0013 & 2.1 & 2 & 0 & 0 \\
18 & -13.3 & 0.0012 & 2.1 & 3 & 0 & 0 \\
19 & -14.5 & 0.0011 & 2.1 & 2 & 0 & 0 \\
20 & -15.6 & 0.001 & 1 & 2 & 0 & 0 \\
21 & -16.8 & 0.0009 & 1 & 2 & 0 & 0 \\
22 & -16.3 & 0.001 & 2.1 & 1 & 0 & 0 \\
23 & -15.7 & 0.001 & 3.1 & 1 & 0 & 0 \\
24 & -15.2 & 0.001 & 4.1 & 0 & 0 & 0 \\
& & & & & & \\
\hline
\end{tabular}




\section{SIMULATION ON THE BASIS OF TRY}

Computer simulation of the thermal performance of a building was made by computer program BSim2000. In a numerical model, such as the one used in BSim2000, every continuous event of the real world is described in discrete time steps. This means that the temporal sequence of various processes, which in reality are modified continuously, is described in the program as changes from one time-step to the next, where the time-steps are of a finite size. The program assumes quasistationary conditions, which means that for the length of time of one time-step, the conditions (for example, the temperatures of the individual components in the building) are assumed to be constant. By using suitably small time-steps, this gives a reasonable approximation of reality $\left[^{2}\right]$.

Simulation of thermal performance is provided for a typical old 60-apartment building $\left[{ }^{3,4}\right]$ on the basis of the Estonian TRY. Thermal transmittance values of the envelope elements of the investigated building are given in Table 2 and average free heat data in Table 3.

Air change dependence on the ambient temperature and wind velocity, for a day in the investigated building is given in Fig. 1.

Relative humidity duration graph of the indoor air in the simulated building for the period September-May is presented in Fig. 2. It shows during which percentage of the period relative humidity is higher than the value on the curve. Relative humidity variation is large. Air change rate duration graph for the September-May period is shown in Fig. 3. It shows during which percentage of the period the air change rate is lower than the value on the curve. For the September-May period the average monthly air change rate is from 0.4 to 0.6 .

Table 2. Thermal transmittance values of the envelope elements of the building

\begin{tabular}{l|c}
\hline $\begin{array}{c}\text { Envelope element } \\
\text { of the building }\end{array}$ & $\begin{array}{c}\text { Thermal transmittance, } \\
\mathrm{W} /\left(\mathrm{m}^{2} \mathrm{~K}\right)\end{array}$ \\
\hline Window & 2.70 \\
External wall & 1.03 \\
Roof & 0.91 \\
Floor & 1.19
\end{tabular}

Table 3. Average free heat data for the building

\begin{tabular}{l|c}
\hline \multicolumn{1}{c|}{ Free heat component } & $\begin{array}{c}\text { Average free } \\
\text { heat, } \mathrm{W} / \mathrm{m}^{2}\end{array}$ \\
\hline From people & 1.6 \\
From lighting & 0.2 \\
From electrical equipment & 0.5
\end{tabular}




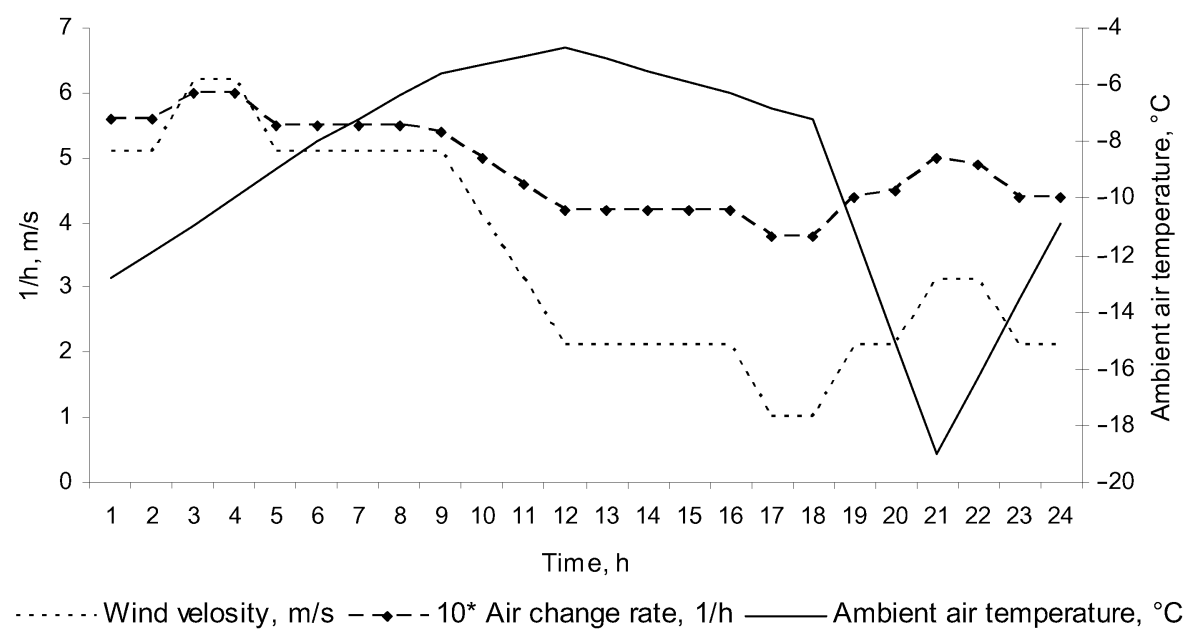

Fig. 1. Daily variation of the ambient temperature, wind velocity and air change rate (1 January).

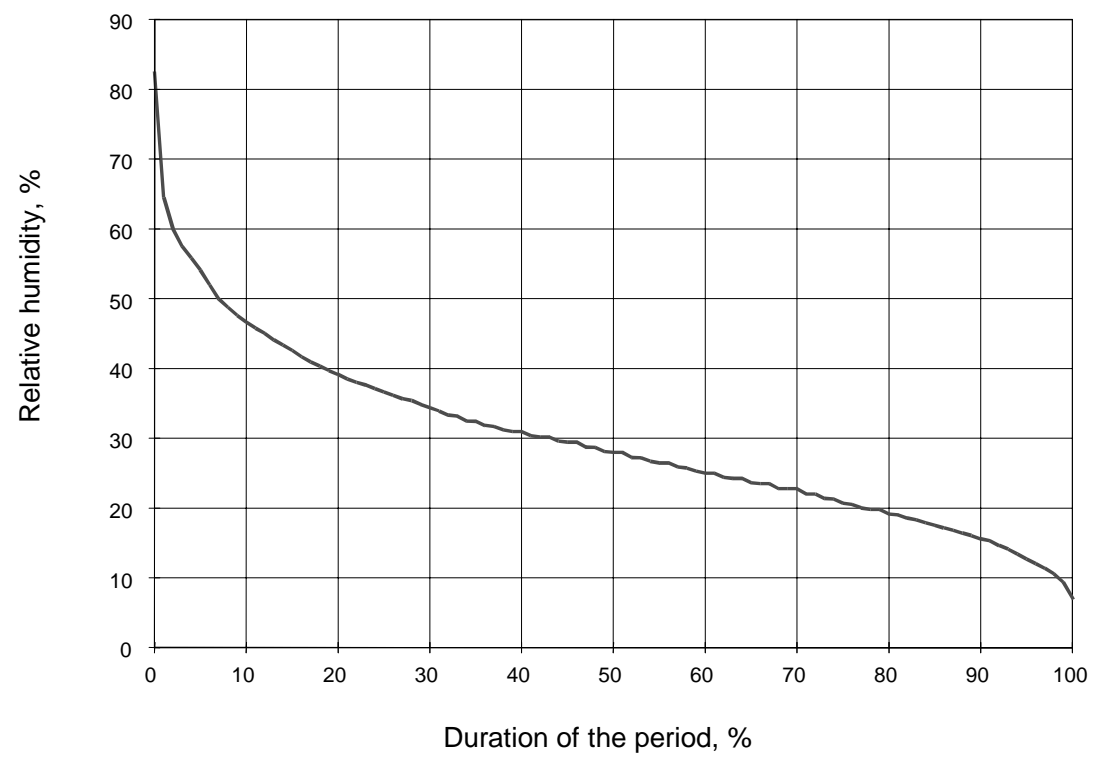

Fig. 2. Relative humidity duration graph of the indoor air in the simulated building for the September-May period.

The air change by natural ventilation consists of three parts: the initial air change, air change that depends on the difference between the indoor and external temperatures, and air change that depends on the wind speed $\left[{ }^{2}\right]$ :

$$
n=n_{0}+c_{\mathrm{t}}\left(t_{\mathrm{i}}-t_{\mathrm{e}}\right)^{0.3}+c_{w} w .
$$




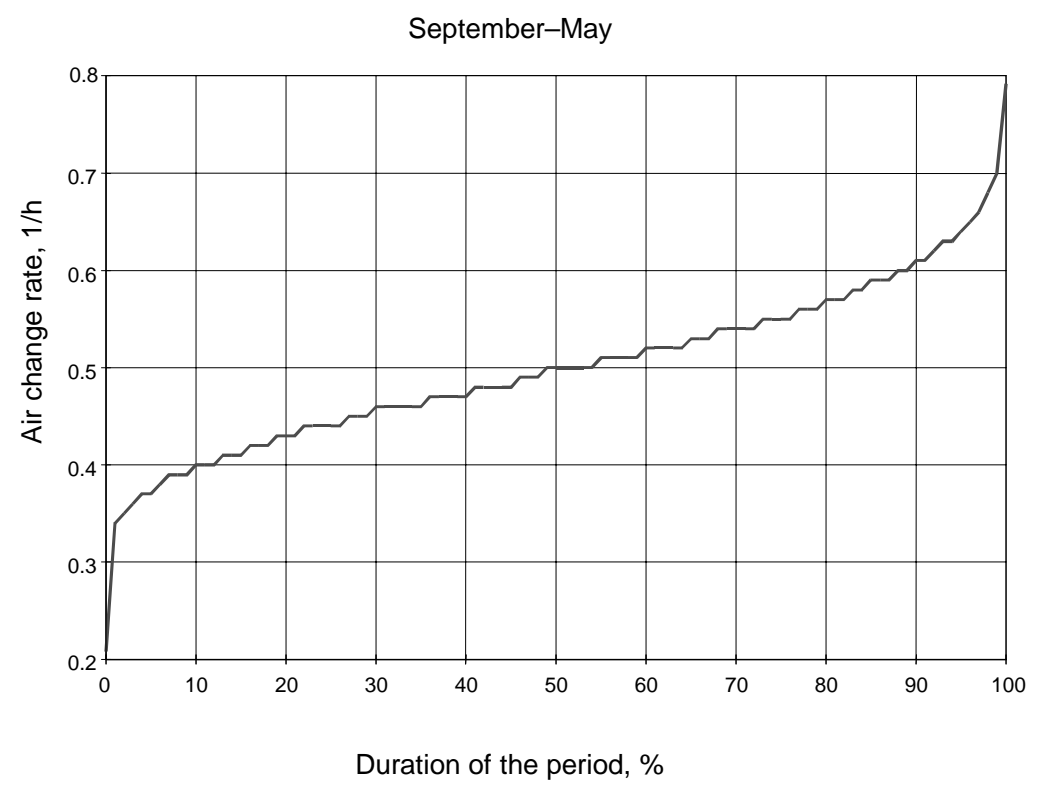

Fig. 3. Air change duration graph of the simulated building for the September-May period.

Here $n_{0}$ is the initial air change rate $\left(\mathrm{h}^{-1}\right.$, in simulation 0.05), $t_{\mathrm{i}}$ is the operative indoor temperature $\left({ }^{\circ} \mathrm{C}\right), t_{\mathrm{e}}$ is the ambient temperature, $c_{\mathrm{t}}$ is a constant that depends in particular on the size of the space and openings and the height difference between the openings (in simulation $c_{\mathrm{t}}=0.1$ ), $c_{\mathrm{w}}$ is a constant that depends in particular on the imperviousness, geometry and location of the building and on the topography of the land (in simulation $c_{\mathrm{w}}=0.04$ ) and $w$ is the wind speed $(\mathrm{m} / \mathrm{s})$.

Heat inflows and heat losses of a typical apartment building of the Test Reference Years for operative temperature of $21^{\circ} \mathrm{C}$ are given in Table 4.

Heat requirements for heating of the building, calculated on the basis of simple degree-days $\left(18^{\circ} \mathrm{C}\right.$ basis $)\left[^{5}\right]$ and obtained with simulation are shown in Fig. 4.

The average difference between the heat requirements, determined by simulation and by calculation on the basis of simple degree-days, was $10 \%$ for the whole heating period, the greatest difference, $28 \%$, occurring in May. This is due to the greatest solar radiation in May among the months of the heating period.

The difference between the yearly actual heat consumption for heating of the investigated apartment building (viewed as an average of 28 buildings with degree-day correction) and the simulated heat requirements was $2 \%$.

Simulation of the heat requirements of the investigated building before and after the renovation of construction elements was carried out. The effect of the insulation of the external walls and of the renovation of windows on heat requirements by simulation and by simple degree-day calculation was analysed. An additional insulation of external walls decreases the U-value from 1.03 to $0.26 \mathrm{~W} /\left(\mathrm{m}^{2} \mathrm{~K}\right)$. In the 
Table 4. Heat balance of the apartment building for the September-May period

\begin{tabular}{|c|c|c|c|c|c|c|c|c|}
\hline \multirow[b]{2}{*}{ Month } & \multicolumn{3}{|c|}{ Heat inflow, MWh } & \multicolumn{2}{|c|}{ Heat losses, MWh } & \multirow{2}{*}{$\begin{array}{c}\text { Ambient } \\
\text { air, } \\
{ }^{\circ} \mathrm{C}\end{array}$} & \multirow{2}{*}{$\begin{array}{c}\text { Air } \\
\text { change } \\
\text { rate, } \\
\mathrm{h}^{-1}\end{array}$} & \multirow{2}{*}{$\begin{array}{c}\text { Relative } \\
\text { humidity } \\
\text { of the } \\
\text { indoor air, } \\
\%\end{array}$} \\
\hline & Heating & $\begin{array}{l}\text { Solar } \\
\text { radi- } \\
\text { ation }\end{array}$ & $\begin{array}{c}\text { Free heat } \\
\text { from people, } \\
\text { lighting and } \\
\text { equipment }\end{array}$ & $\begin{array}{c}\text { Trans- } \\
\text { mission }\end{array}$ & $\begin{array}{l}\text { Infiltra- } \\
\text { tion }\end{array}$ & & & \\
\hline Septembe & 15.9 & 6.0 & 45 & 19.6 & 6.8 & 11.3 & 0.4 & 47.6 \\
\hline October & 33.6 & 3.6 & & 30.7 & 11.2 & 6.7 & & 1 \\
\hline November & 52.2 & 1.7 & & 41. & 16.6 & 1.1 & 0 . & 27.6 \\
\hline December & 68.1 & 0.6 & 4.6 & 50.8 & 22.6 & -2.3 & 0.6 & 22.5 \\
\hline January & 70.2 & 1.8 & 4.6 & 54.2 & 22.4 & -3.7 & 0.5 & 20.4 \\
\hline February & 66.5 & 4.0 & 4.2 & 52.2 & 22.4 & -5.1 & 0.5 & 19.3 \\
\hline March & 57.3 & 7.2 & 4.6 & 48.5 & 20.7 & -1.1 & 0.5 & 22.8 \\
\hline April & 40.4 & 7.1 & 4.5 & 37.0 & 15.0 & 3.3 & 0.5 & 28.5 \\
\hline May & 21.1 & 9.0 & 4.5 & 25.2 & 9.6 & 9.3 & 0.5 & 33.2 \\
\hline Sum/Average & 425.3 & 41.0 & 40.6 & 400.5 & 147.3 & 2.2 & 0.5 & 34.4 \\
\hline
\end{tabular}

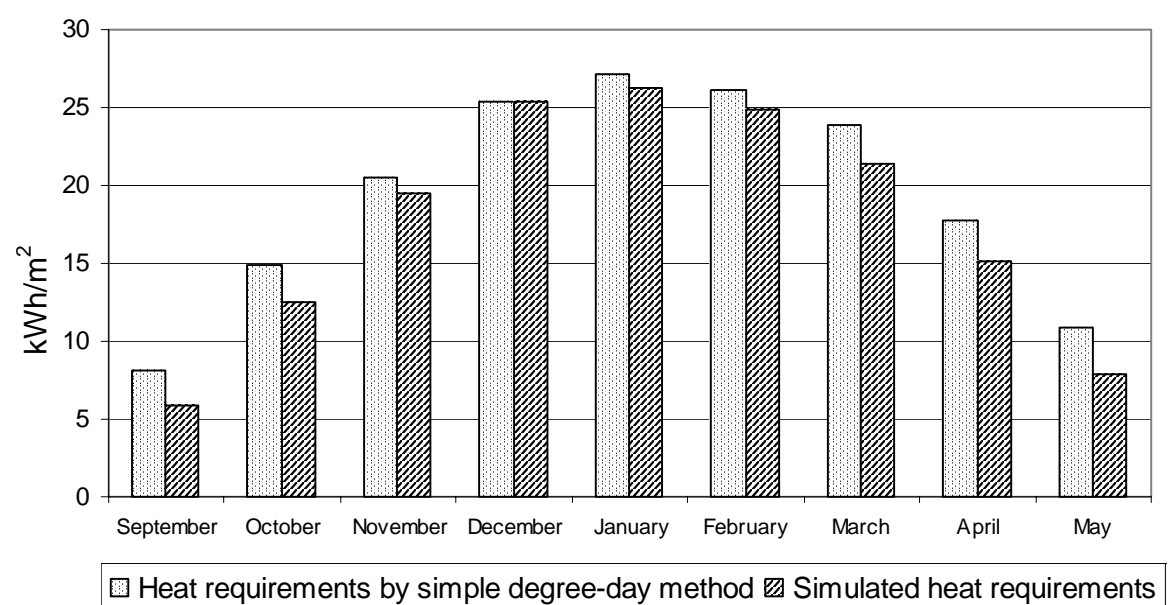

Fig. 4. Heat requirements of the building for heating per gross area, calculated on the basis of simple degree-days and obtained with simulation.

simulation of heat requirements, the effect of the insulation of external walls was $39.2 \mathrm{kWh} / \mathrm{m}^{2}$, by simple degree-day calculation only $2 \%$ less. Next we concentrated on observing the change of a window: the U-value and solar radiation transmittance coefficient decreased from 2.7 to $1.4 \mathrm{~W} /\left(\mathrm{m}^{2} \mathrm{~K}\right)$ and from 0.76 to 0.56 , respectively. Simulation of heat requirements gives a decrease of $19.7 \mathrm{kWh} / \mathrm{m}^{2}$ and simple degree-day calculation for $10 \%$ more. Thus determination of heat requirements by simulation is more correct. The reason for that is a decrease in the useful solar radiation rate in the building heat balance (see Fig. 5) that is not taken into account by the degree-day calculation. 


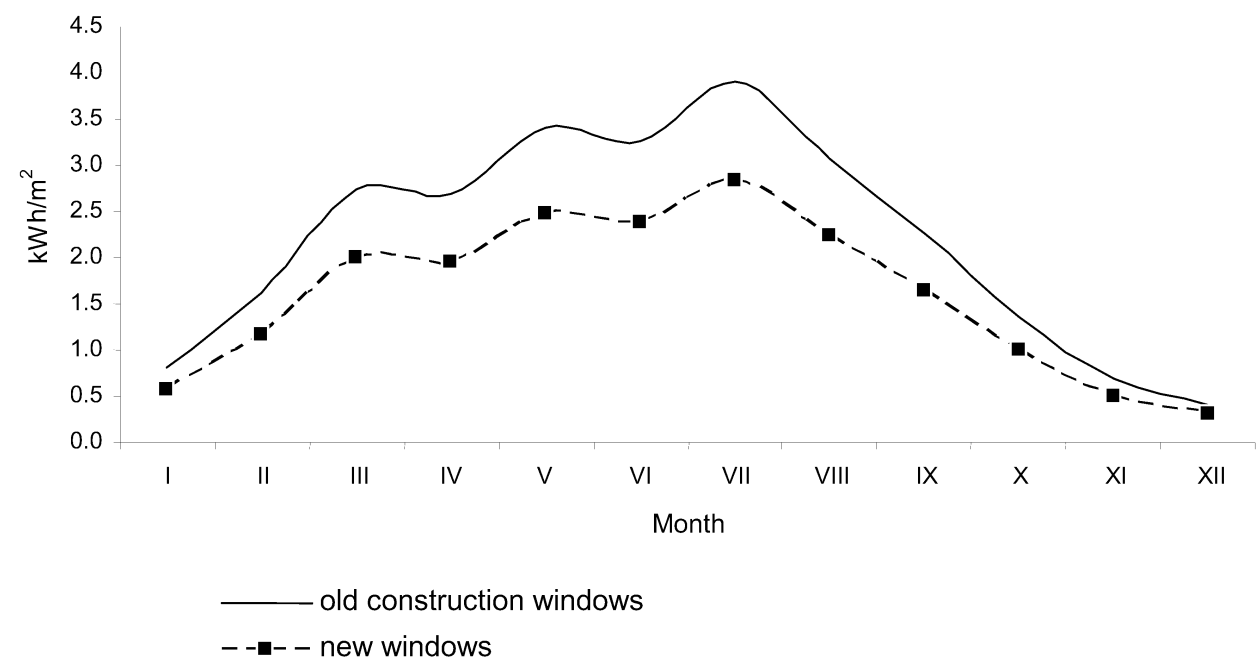

Fig. 5. Heat inflow of solar radiation through existing and changed windows.

For the same reason, the position of the building with regard to the cardinal points affects the heat requirements. For example, if we turn the building with E-W façade for $90 \mathrm{deg}$, heat requirements decrease by $2.5 \%$ for a building with old construction windows.

Dependence of the heating load of the building on ambient temperature, presented in Figs. 6 and 7, has been obtained on the basis of simulated average heating loads of different days. Figure 6 shows heating load for the period from

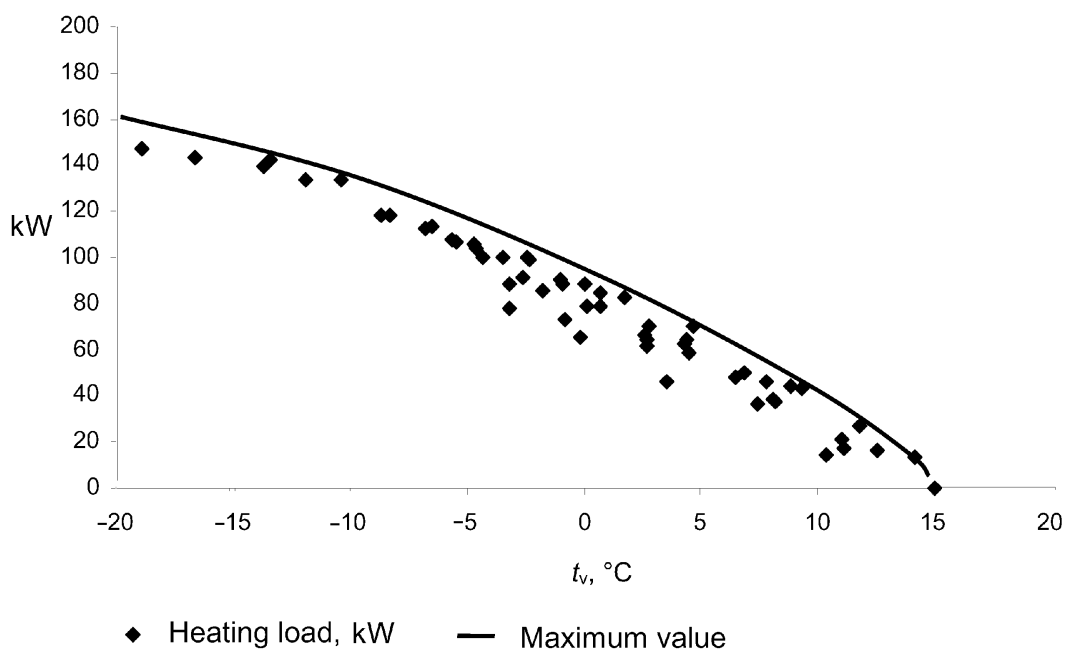

Fig. 6. Dependence of the heating load of the building on the ambient temperature and maximum value graph for the period September-January. 


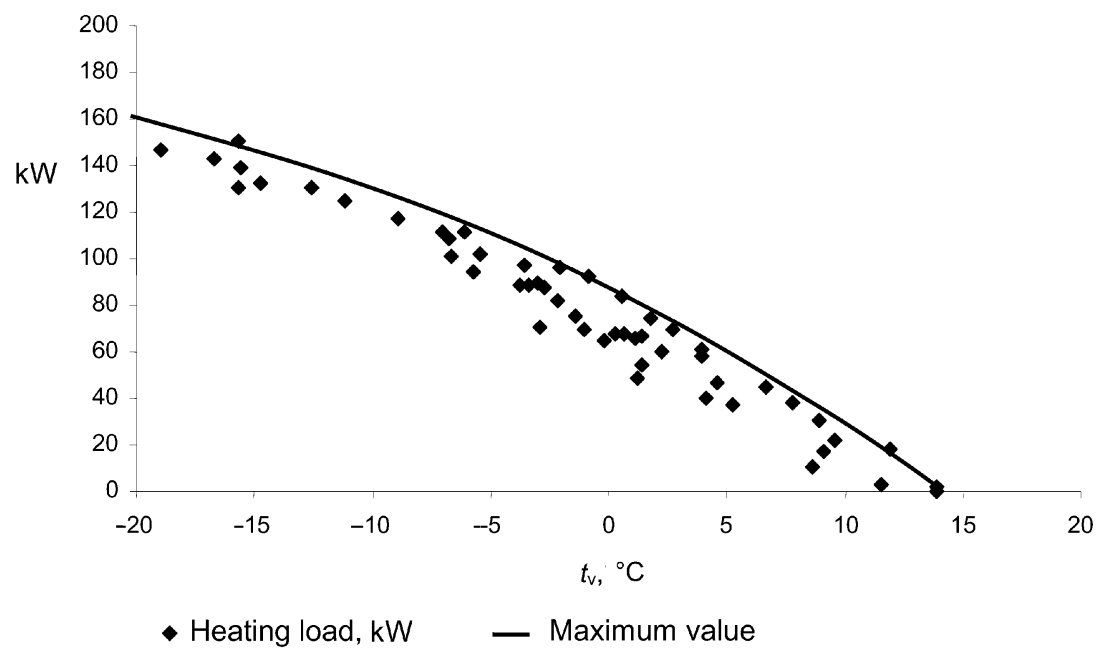

Fig. 7. Dependence of the heating load of the building on the ambient temperature and maximum value graph for the period January-May.

September to January and in Fig. 7 for the period from January to May. For these two periods the influence of the solar radiation is different. For ambient temperature below $0^{\circ} \mathrm{C}$ the load difference of the first and the second period is very small. But for higher ambient temperatures the heating load for the second period is up to $20 \%$ smaller for the same ambient temperature. These results are important for composing temperature graphs of central control for buildings without individual control of the temperature (without thermostats on heating coils) and energy saving.

In Figs. 6 and 7 we see a difference in average ambient temperatures for the spring period, when heating is finished $\left(13-14^{\circ} \mathrm{C}\right)$, and for the autumn period, when heating is started $\left(15^{\circ} \mathrm{C}\right)$. That helps us to determine the real heating load of the building. For the investigated building it is about $25 \%$ less than the designed load.

\section{CONCLUSIONS}

Simulation of heat requirements and indoor temperatures is an effective tool for investigating the thermal performance of a building. The simulation was especially useful for determining the influence of the solar radiation.

The compiled model of the building is close to reality: the yearly difference in the simulated heat consumption for heating is $2 \%$ when compared with the yearly actual consumption with the degree-day correction. The simulated heat requirements are $10 \%$ less than those obtained by using the simple degree-day method. 
The results of the simulation give information on different heating loads for the autumn and spring periods for the same ambient temperature conditions. Applying the results of the heating load analysis in apartment buildings without automatic temperature control on heating coils, heat consumption for heating can be reduced.

\section{ACKNOWLEDGEMENTS}

The authors are grateful to the Estonian Institute of Meteorology and Hydrology and especially to the Tartu Meteorological Station for their help with climate data collection.

\section{REFERENCES}

1. Test Reference Years TRY. Commission of the European Communities. Directorate General XII for Science, Research and Development. Brussels and Luxemburg, 1985.

2. Wittchen, K. B., Jonsen, K. and Grau, K. BSim2000 User's Guide. Danish Building Research Institute, Hørsholm, 2000.

3. Kõiv, T.-A. and Kusnetsov, K. Thermal performance of typical residential buildings. Proc. Estonian Acad. Sci. Eng., 2003, 9, 59-66.

4. Kurnitski, J. and Sasi, L. Kerrostalojen ilmanvaihdon parannusratkaisut Virossa. Helsinki University of Technology, Espoo, 1996.

5. Kreider, J. F., Curtiss, P. S. and Rabl, A. Heating and Cooling of Buildings. McGraw-Hill, New York, 2002.

\section{Kortermaja soojusliku käitumise modelleerimine}

\section{Kadi Kusnetsov ja Teet-Andrus Kõiv}

On kirjeldatud modelleerimise kasutamist hoone soojusliku käitumise uurimisel, eriti päikesekiirguse mõju määramisel. Koostatud hoone mudel on lähedane tegelikule olukorrale: võrreldes kraadpäevadega korrigeeritud tegeliku aastase soojatarbimisega kütteks, on modelleeritud tarbimise erinevus $2 \%$. Lihtsate kraadpäevade abil saadud tulemusega võrreldes on soojatarbimise modelleerimisega saadud soojavajadus kütteks kortermajades $10 \%$ väiksem. Modelleerimise tulemused annavad infot erinevatest küttevajadustest sügis- ja kevadperioodil samade välisõhu temperatuuride juures. Kasutades kortermajade küttekoormuse analüüsi tulemusi, saab vähendada soojatarbimist kütteks küttekehade automaatregulaatorite puudumisel. 